\title{
Ryzyko polityczne w zarządzaniu długiem lokalnym w Polsce
}

\section{Streszczenie}

$\mathrm{W}$ artykule przedstawiono zagadnienia związane $\mathrm{z}$ występowaniem ryzyka politycznego w samorządzie lokalnym w Polsce. Podjęto próbę zidentyfikowania możliwości wystąpienia politycznego cyklu budżetowego w jednostkach samorządu terytorialnego. Na podstawie danych ze sprawozdań budżetowych została przeprowadzona analiza empiryczna finansów samorządowych z uwzględnieniem poziomu zadłużenia, wydatków majątkowych, a także wyniku budżetu. Prezentowane rezultaty badań obejmują wszystkie kategorie jednostek samorządu terytorialnego, tj. gminy, miasta na prawach powiatu, powiaty i województwa. Analiza obejmuje lata 2003-2019. Szczególne zainteresowanie wzbudziły lata wyborcze i okresy przedwyborcze. Część empiryczną poprzedza przegląd literatury zarówno w zakresie cyklu wyborczego, jak i ryzyka w zarządzaniu długiem lokalnym. Przyjęta struktura artykułu umożliwia uzyskanie odpowiedzi na pytanie: Czy ryzyko polityczne występuje w badanych podmiotach?

Słowa kluczowe: ryzyko polityczne, dług lokalny, finanse samorządu terytorialnego Kody klasyfikacji JEL: H63, H74, H76

\footnotetext{
1 Gnieźnieńska Szkoła Wyższa Milenium, e-mail: daniel.budzen@milenium.edu.pl, https://orcid. org/0000-0003-0895-6181
} 


\title{
Political risk in local debt management in Poland
}

\begin{abstract}
The article presents issues related to the occurrence of political risk in local government in Poland. It will attempt to identify the symptoms to demonstrate the possibility of a political budget cycle in local government units. On the basis of budgetary data an empirical analysis of local governments will be carried out, with a particular emphasis on debt levels, capital expenditures, and a result of the budget in the years of local elections and pre-election periods. The presented research results cover all categories of local government units, i.e., municipalities, cities with poviat rights, poviats, and voivodships. The time range of the analysis is 2003-2019. The empirical part is preceded by a literature review, both in terms of the election cycle and the risk related to local debt management. The adopted structure of the article allows obtaining an answer to the question of whether there is a political risk in the surveyed entities.
\end{abstract}

Keywords: political risk, local debt, local government finance

JEL Classification Codes: H63, H74, H76

Problematyka wyborów parlamentarnych lub prezydenckich w kontekście polityki fiskalnej państwa była wielokrotnie przedmiotem rozważań ekonomistów. W teorii ekonomii została określona mianem politycznego cyklu budżetowego. Stosunkowo uboga literatura dotycząca powiązania ryzyka politycznego z długiem lokalnym w Polsce stanowi przyczynę do podjęcia rozważań w powyższym obszarze. Przedmiotem badania jest ryzyko polityczne w ramach jednostek samorządu terytorialnego (dalej: JST) w odniesieniu do procesu zarządzania długiem lokalnym.

W pierwszej części artykułu przedstawiono przegląd literatury na temat politycznego cyklu budżetowego. Skoncentrowano uwagę na zależnościach zachodzących pomiędzy kształtowaniem się deficytu budżetowego, struktury wydatków i zadłużenia a preferencjami ugrupowań politycznych dążących do uzyskania poparcia w wyborach (parlamentarnych lub samorządowych). Założono istnienie racjonalnego lub nieracjonalnego wyborcy.

$\mathrm{W}$ drugiej części przedstawiono rodzaje ryzyka związanego z zarządzaniem długiem lokalnym. Na potrzeby rozważań zostały wyszczególnione trzy kategorie ryzyka: rynkowe, finansowe i operacyjne. Ryzyko polityczne sklasyfikowano jako ryzyko operacyjne. Jest to podyktowane tym, że sprawowanie kontroli w tym zakresie należy do kompetencji organów JST oraz związane jest bezpośrednio z działalnością samorządu terytorialnego i uwarunkowane realizacją założeń polityki ugrupowań sprawujących władzę. 
Celem artykułu jest udzielenie odpowiedzi na pytanie: Czy JST w Polsce są narażone na ryzyko polityczne? Na potrzeby uzyskania odpowiedzi na tak postawione pytanie podjęto próbę obserwacji wybranych wielkości budżetowych, w szczególności w latach wyborczych i poprzedzających wybory do organów JST o rok. Na podstawie danych ze sprawozdawczości budżetowej dla lat 2003-2019 przeprowadzono analizę empiryczną, ze szczególnym uwzględnieniem wyniku budżetu, poziomu zadłużenia i wydatków majątkowych z wyodrębnieniem poszczególnych typów JST.

\section{Polityczny cykl budżetowy w teorii ekonomii}

Próby zwrócenia uwagi i wyjaśnienia kwestii związanych z deficytem budżetowym i zadłużeniem władz publicznych były wielokrotnie podejmowane przez ekonomistów. Tematyka ta stanowi punkt wyjścia do podjęcia dalszych rozważań nad ryzykiem politycznym w obszarze zarządzania długiem lokalnym. Warto w tym miejscu przytoczyć poglądy Keynesa na temat deficytu budżetowego. Ujemny wynik budżetu był efektem interwencjonizmu państwowego mającego na celu m.in. stymulowanie popytu i próby pobudzenia gospodarki znajdującej się w kryzysie. Na uwagę zasługują prace A.P. Lernera i A.H. Hansena (zob. Próchnicki, 2012: 166), którym przypisuje się sformułowanie odpowiednio koncepcji finansów funkcjonalnych i budżetu operacyjnego. Odrzucili oni założenie o utrzymaniu równowagi budżetowej w ciągu roku kalendarzowego, traktując ją jako jeden z elementów mechanizmu gospodarki rynkowej. Uważali, że właściwym momentem dla zaciągnięcia długu jest recesja gospodarcza. Hansen natomiast sformułował górny poziom zadłużenia, którym jest relacja długu do PKB. Zauważyć należy, że w wielu krajach miernik ten funkcjonuje do dziś i służy ocenie stabilności finansowej.

Późniejsze doświadczenia podały w wątpliwość teorie ukierunkowane na interwencjonizm państwowy czy też zbawczą rolę deficytu budżetowego. Zaczęły się pojawiać poglądy traktujące o tym, że równowaga może zachodzić zarówno przy pełnym, jak również niepełnym zatrudnieniu. J.M. Buchanan (zob. Stankiewicz, 2007: 418), który jest uznawany za jedną z kluczowych postaci ekonomii politycznej, definiuje politykę jako proces wymiany, do analizy którego wykorzystuje metody ekonomiczne. Jako podstawę analizy przyjął indywidualne oraz prywatne zachowania osób zdolnych do podejmowania racjonalnych decyzji, które w konsekwencji wywierają wpływ na ogół społeczeństwa. J.M. Buchanan i G. Tullock (zob. Stankiewicz, 2007: 418) badali zachowanie wyborców, podatników, kandydatów na polityków i członków partii. Postępowanie tych osób jest istotne, bowiem kształtuje sferę polityczną, a w konsekwencji społeczno-gospodarczą. 
Zarówno teorię deficytu i równowagi budżetowej, jak i poglądy ekonomii politycznej należy łączyć z politycznym cyklem koniunkturalnym, określanym w literaturze również jako budżetowy. W literaturze ekonomicznej dość często podnosi się, że pierwszym, który zwrócił uwagę na tę problematykę, był ekonomista polskiego pochodzenia - M. Kalecki (1943: 323-326). Do tematyki tej nawiązał m.in. przy okazji rozważań nad umiejscowieniem aspektów politycznych w osiągnięciu stanu pełnego zatrudnienia w gospodarce. Wskazywał, że prowadzenie polityki zmierzającej do osiągnięcia pełnego zatrudnienia w gospodarce stanowi ryzyko szczególnie wówczas, kiedy jest ona finansowana przy pomocy pożyczek lub kredytów. Takie działanie może prowadzić do inflacji. Wyrażając sprzeciw wobec polityki wydatkowej rządu ukierunkowanej na osiągnięcie stanu pełnego zatrudnienia, wskazywał m.in. na niechęć biznesu do interwencji państwa. Zwrócił także uwagę na obawy środowiska biznesowego w kontekście dotowania konsumpcji oraz kierunków inwestycji publicznych. Takie działania mogą prowadzić do powstania efektu wypychania produkcji prywatnej przez sferę publiczną. Jako kolejne ryzyko Kalecki wskazuje, że przy pełnym bezrobociu słabnąć będzie społeczna pozycja menedżera, natomiast rosnąć - pewność siebie klasy robotniczej. Konsekwencją tych działań będą strajki w celu uzyskania podwyżki płac lub poprawy warunków pracy.

Trudno się nie zgodzić z przytoczonymi poglądami, bowiem częstotliwość manifestacji społecznych szczególnie przybiera na sile w okresach przedwyborczych. Widoczny jest wówczas nacisk społeczny na polityków, czego następstwem jest zwiększanie wydatków publicznych lub zmiana ich struktury. W konsekwencji ma to zagwarantować politykom powtórny wybór.

Wiele źródeł podaje, że pierwszym, który oficjalnie zaprezentował model politycznego cyklu budżetowego, jest W. Nordhaus (zob. Działo, 2007: 27). Przyjął on założenie, że w celu zdobycia poparcia wyborców i zwiększenia szans na reelekcję politycy wykorzystują ekspansywną politykę fiskalną. Model ten uwzględnia oportunistyczne partie, których członkowie są wybierani przez nieracjonalnych wyborców. Społeczeństwo nie wyciąga sankcji wobec polityków przy następnych wyborach. Taką karą dla polityków byłoby nieudzielenie poparcia w związku z recesją, która według Nordhausa ma się pojawić krótko po wyborach. Zaprezentowany model zakładał, że krótko po wyborach polityka rządu będzie ukierunkowana na wzrost bezrobocia, bankructwa firm, tym samym redukując presję inflacyjną. Następnie przed wyborami nastąpiłaby obniżka podatków czy też utrzymywanie stóp procentowych na niskim poziomie. Zamysłem takich działań jest nie tylko uzyskanie reelekcji, ale również osiągnięcie wzrostu gospodarczego kraju. Prowadziłoby to do świadomego manipulowania wyborcami, którzy w dniu wyborów mieliby w pamięci jedynie poprawę koniunktury gospodarczej, a nie recesję (Samuelson, Nordhaus, 2000: 311). 
Model stronniczych polityków przedstawił m.in. D. Hibbs (1977: 1470-1473). Z jednej strony zwraca on uwagę na zależności między inflacją i bezrobociem, a z drugiej strony zakłada istnienie partii lewicowych i prawicowych. Zauważa, że w przypadku elektoratów partii politycznych zawsze występowały różnice dotyczące interesów gospodarczych poszczególnych grup zawodowych czy też kwestii dochodowych. Partie lewicowe są zorientowane na klasę robotniczą i przywiązują większą wagę do uzyskania pełnego zatrudnienia aniżeli skupiają się na inflacji. Natomiast partie prawicowe są zorientowane na utrzymanie stabilności cen bardziej niż na redukcję bezrobocia. Na podstawie przeprowadzonych badań ustalono, że w przypadku krajów, w których władzę sprawowały partie lewicowe, stosunkowo niska była stopa bezrobocia, a wyższa stopa inflacji. W przypadku partii prawicowych sytuacja była odwrotna. Zestawienie celów poszczególnych partii politycznych pokazuje, że dla ugrupowań lewicowych najważniejszym celem jest dążenie do stanu pełnego zatrudnienia oraz wyrównanie dysproporcji w dochodzie ludności. Ponadto partie robotnicze dążyły do ekspansji ekonomicznej, stabilności cen i równowagi bilansu płatniczego. Partie prawicowe, określane również jako konserwatywne, swoje działania ukierunkowywały przede wszystkim na stabilność cen, równowagę bilansu płatniczego i ekspansję ekonomiczną. Ograniczanie stopy bezrobocia i wyrównywanie nierówności w dochodach były celami najmniej ważnymi.

Model kompetencyjnych polityków przy wykorzystaniu krzywej Philipsa przedstawiają T. Persson i G. Tabellini (2003). Jest to cecha wspólna wcześniej przytoczonych modeli, a zwłaszcza modelu zaprezentowanego przez Nordhausa. Zasadniczą różnicą jest to, że w rozważaniach Nordhausa wyborcy są podatni na manipulacje, nie kierują się racjonalnością (Samuelson, Nordhaus, 2000: 311). Natomiast Persson i Tabellini (zob. Działo, 2007: 34) traktują o elektoracie racjonalnym, tj. o takim, który nie kieruje się wyłącznie informacjami uzyskanymi w przeszłości, ale w swoich wyborach uwzględnia bieżące treści oraz analizę sytuacji społeczno-gospodarczej. U podstaw modelu funkcjonuje założenie o kompetentności polityków. Wyborcy postrzegają ich kompetencje z jednookresowym opóźnieniem, co zachęca partie polityczne do stymulowania wzrostu gospodarczego. Poziom kompetencji polityków jest utożsamiany z kondycją gospodarki w roku wyborczym. Poczynione założenie o trwałości kompetentności polityków powoduje, że kiedy wybory przypadają w czasie dobrej koniunktury gospodarczej, wyborcy nie wykazują woli dokonania zmiany rządzących. Model ten generuje więc krótkookresowe cykle wyborcze, które są związane z asymetrią informacji oraz opóźnieniami. Persson i Tabellini (2003: 14) udzielili twierdzącej odpowiedzi na postawione pytanie, czy cykle wyborcze różnią się w poszczególnych systemach politycznych. Badaniu poddali problematykę wyborów parlamentarnych i prezydenckich. Cykle wyborcze są bowiem widoczne dla 
obu typów wyborów, jednak mogą przybierać różne formy. W przypadku wyborów większościowych rząd może zmniejszyć zarówno wydatki, jak i podatki w sposób bardziej widoczny niż w przypadku demokracji proporcjonalnej.

Rozważania nad politycznym cyklem budżetowym zaprezentowali również K. Rogoff i A. Sibert (1988:2). W swoich badaniach dowodzili zróżnicowanych kompetencji polityków. Zauważyli, że wyborcy preferują bardziej kompetentne rządy. Społeczeństwo dostrzega kompetencje rządu z opóźnieniem. Wyborcy są zainteresowani desygnowaniem polityków kompetentnych bez względu na to, czy jest to partia rządząca, czy też opozycyjna. Partie opozycyjne mają trudność, aby wysłać społeczeństwu wiarygodny sygnał odnośnie do efektywności składanych obietnic. Takiego problemu nie ma partia rządząca. Asymetryczne informacje zastępują w tym modelu krótkowzroczność wyborców. Mają oni racjonalne oczekiwania, jednak pozbawieni są pewności w zakresie kompetentności polityków. W celu zasygnalizowania kompetencji partia wyborcza może dążyć do zwiększenia wydatków już w okresie przedwyborczym (Veiga L.G., Veiga F.J., 2004: 3).

$\mathrm{Na}$ koniec rozważań dotyczących teorii politycznego cyklu budżetowego warto wspomnieć o koncepcji A. Alesiny (zob. Pacześ, 2011: 219), w której wyborcy mają pełną informację związaną z sytuacją społeczno-gospodarczą kraju, natomiast ugrupowania polityczne kierują się względami czysto ideologicznymi. Jest to model stronniczych polityków oraz racjonalnych wyborców. Omawiany cykl może wystąpić $w$ takiej sytuacji, ale jest on uzależniony m.in. od polaryzacji programów sił politycznych, a także niepewności związanej z ponownym wyborem. Warto zauważyć, że deficyt budżetowy oraz przyrost zadłużenia mogą stanowić instrumenty polityczne w przypadku następujących po sobie rządów charakteryzujących się odmiennymi poglądami. Zarówno deficyt budżetu, jak również zadłużenie mogą wywierać wpływ na decyzje następców. Jak podkreślają Alesina i Tabellini (1990: 403-412), jest to widoczne w przypadku rządów konserwatywnych i liberalnych.

\section{Ryzyko w zarządzaniu długiem lokalnym}

Polityczny cykl budżetowy jest bezpośrednio związany z okresem wyborczym i działaniami polityków (m.in. sprawujących władzę), którzy dążą do reelekcji. W tej części artykułu zwraca się uwagę na najistotniejsze rodzaje ryzyka, na które narażeni są zarządzający długiem lokalnym.

Zarządzanie długiem lokalnym jest procesem, który z jednej strony polega na określeniu zdolności do zaciągania długu oraz jego spłaty, a z drugiej strony na najefektywniejszym wykorzystaniu wszystkich dostępnych źródeł finansowania 
zwrotnego. Ryzyko związane z wybranym instrumentem dłużnym powinno być niższe niż w pozostałych przypadkach. Proces przekazywania zobowiązań finansowych władzom kolejnej kadencji lub nawet przyszłym pokoleniom jest bardzo istotny, dlatego też wymaga on zrozumienia i racjonalnie podjętych decyzji w kontekście zaciągnięcia długu (Cichocki, 2013: 51-52).

W celu zrozumienia konieczności i skutków obciążenia przyszłych pokoleń nowym długiem niezbędne jest sformułowanie strategii zarządzania nim. Strategia jest opracowywana dla sektora finansów publicznych, natomiast władze JST nie są do tego zobligowane. Mogłoby się wydawać, że ramy zarządzania długiem powinny być ukierunkowane wyłącznie na minimalizację kosztów. Jednak istotnym elementem, który należy wziąć pod uwagę, jest niewątpliwie ryzyko towarzyszące tym procesom (szczególnie w sytuacji niepewności i zmienności otoczenia społeczno-gospodarczego).

Ocena kryteriów w zakresie zarządzania długiem jest związana również ze sposobem wykorzystania długu zarówno długo, jak i krótkoterminowego. Proces decyzyjny w analizowanym obszarze obejmuje m.in. ekspozycje na ryzyko stopy procentowej, kursowe czy też refinansowania. Ponadto w przypadku oceny czynników ryzyka indywidualnego brane są pod uwagę strategie zarządzania ryzykiem, z których wynika w szczególności świadomość istnienia poszczególnych zagrożeń oraz ich wpływ na zdolność i wiarygodność kredytową (Bitner, Cichocki, Sierak, 2013: 229).

Klasyfikacja rodzajów ryzyka jest przedmiotem wielokrotnych rozważań literaturowych. W celu zapewnienia przejrzystości niniejszych rozważań zaproponowano wyodrębnienie trzech głównych kategorii ryzyka zgodnie z tabelą 1 .

Tabela 1. Podstawowe kategorie ryzyka w zarządzaniu długiem lokalnym

\begin{tabular}{|l|l|}
\hline \multicolumn{1}{|c|}{ Kategoria } & \multicolumn{1}{c|}{ Ryzyko } \\
\hline Ryzyko rynkowe & Ryzyko stopy procentowej \\
& Ryzyko inflacji \\
& Ryzyko kursowe \\
\hline Ryzyko finansowe & Ryzyko kredytowe \\
& Ryzyko fiskalne \\
& Ryzyko refinansowania \\
\hline Ryzyko operacyjne & Ryzyko wiarygodności i komunikacji \\
& Ryzyko polityczne \\
& Ryzyko organizacyjno-prawne \\
& Ryzyko techniczne (informatyczne) \\
& Ryzyko zdarzeń nadzwyczajnych \\
\hline
\end{tabular}

Źródło: opracowanie własne na podstawie Marchewka-Bartkowiak (2008: 110-116).

Pierwszą z wymienionych grup jest ryzyko rynkowe, które jest determinowane czynnikami zewnętrznymi, niezależnymi od działań władz lokalnych. Jest ono bezpośrednio powiązane z kosztem pozyskania finansowania dłużnego. W tej kategorii 
należy wyróżnić ryzyko stopy procentowej, na które bezspornie narażone są wszystkie samorządy mające dług. Miarą oceny tego ryzyka jest duracja długu. Wskaźnik umożliwia wyznaczenie akceptowalnego poziomu wrażliwości kosztów obsługi długu na zmianę stóp procentowych. Szczególnego znaczenia nabiera to w przypadku finansowania potrzeb pożyczkowych instrumentami dłużnymi w perspektywie długookresowej. W przypadku zobowiązań długoterminowych posiadanie zrównoważonego portfela długu będzie wyznacznikiem elastyczności i umożliwi dostosowanie obecnej struktury długu względem planowanych nowych zobowiązań. Natomiast w przypadku krótkiego horyzontu czasowego głównym czynnikiem decydującym o wyborze stopy oprocentowania będzie minimalny koszt (Kamiński, 2012: 200).

Ryzyko inflacji wywiera wpływ na ocenę realnych kosztów zadłużenia. W przypadku wzrostu ogólnego poziomu cen będzie ono zjawiskiem pozytywnym, ponieważ konsekwencją tego będzie spadek realnej wartości długu. Natomiast w przeciwnym wypadku oraz w sytuacji zwiększonych oczekiwań inwestorów w stosunku do poziomu inflacji ryzyko to będzie wywierało negatywne skutki dla zarządzających długiem. W takiej sytuacji wystąpi wzrost realnej kwoty zadłużenia oraz wyższa premia za ryzyko w momencie emisji instrumentów dłużnych (Marchewka-Bartkowiak, 2008: 111-112).

Z ryzykiem kursowym JST mają do czynienia nie tylko przy dokonywaniu wydatków opartym na walutach obcych, ale również w przypadku zadłużenia denominowanego w walutach obcych. Szczególnie przy zaciąganiu zobowiązań w obcych walutach należy mieć na względzie dywersyfikację portfela długu. W tym przypadku również negatywny skutek może wywrzeć omówione wcześniej ryzyko stopy procentowej, co powoduje, że oba rodzaje ryzyka mogą wystąpić jednocześnie (Denek, Dylewski, 2013: 285).

JST są narażone również na ryzyko kursowe. Pokazuje to rysunek 1, na którym widoczny jest wzrost udziału długu zagranicznego w ogólnej strukturze zadłużenia samorządów w Polsce w latach 2003-2019. W 2003 r. udział długu zagranicznego w zobowiązaniach ogółem wynosił 4,3\%, następnie w 2005 r. przekroczył poziom $10 \%$, a w 2016 r. osiągnął najwyższy poziom, tj. 22,5\%. Począwszy od 2015 r. widoczna jest stabilizacja udziału długu zagranicznego w portfelu zadłużenia JST, który kształtuje się na poziomie 21,6\% (2015 r.) i 21,8\% (2019 r.).

Drugą kategorią, która została wyszczególniona na potrzeby niniejszych rozważań, jest ryzyko finansowe. Obejmuje ono czynniki zewnętrzne - niezależne od JST, a także czynniki wewnętrzne, które samorząd może kontrolować. Pierwotnie mogą one nie stwarzać znacznych zagrożeń czy też perturbacji w kontekście stabilności finansowej JST. 
Rysunek 1. Struktura walutowa długu lokalnego w Polsce w latach 2003-2019 (w \%)

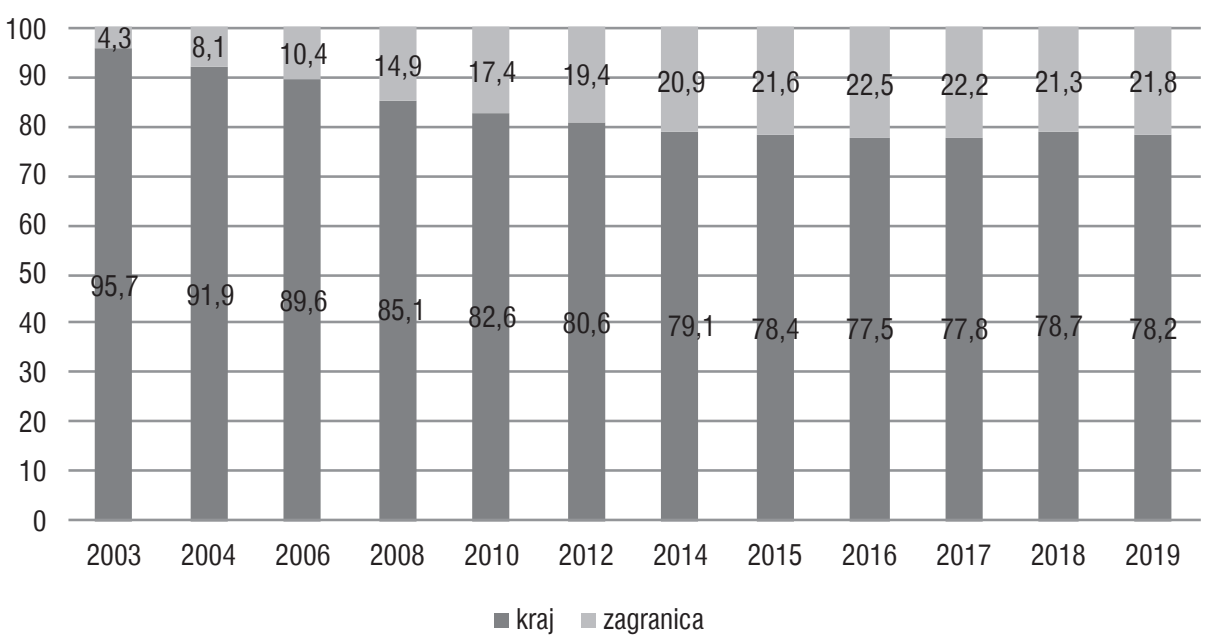

Źródło: opracowanie własne na podstawie baz danych Ministerstwa Finansów (2020).

Ryzyko kredytowe jest związane z sytuacją niewywiązania się przez drugą stronę transakcji ze swojego zobowiązania. Powstaje ono podczas dokonywania transakcji, których przedmiotem są należności. Ryzyko może się zmaterializować w przypadku zarządzania płynnymi aktywami - dokonywania lokat wolnych środków pieniężnych oraz nabywania papierów wartościowych (Ministerstwo Finansów, 2019: 41). Przedmiotowe ryzyko może wystąpić również w przypadku udzielania z budżetu JST pożyczek innym podmiotom oraz udzielania przez władze lokalne poręczeń i gwarancji. Kluczowym aspektem minimalizacji zagrożeń z tym związanych jest precyzyjna ocena wiarygodności kredytowej i ocena sytuacji finansowej drugiej strony transakcji, a także w przypadku lokowania wolnych środków - monitoring wpływów do budżetu i harmonogram dokonywanych wydatków. Ryzyko kredytowe powinno być oceniane i zarządzane przez zarządzających długiem i aktywami płynnymi. W celu minimalizacji zagrożenia należałoby zapewnić spójność celów i działań we wskazanych wyżej obszarach zarządzania finansami lokalnymi. Ponadto istotne jest, aby zarządzanie ryzykiem kredytowym było wsparte przejrzystymi procedurami. Z kolei ocena wiarygodności i zdolności kredytowej drugiej strony transakcji powinna być dokonana w sposób możliwie najbardziej obiektywny, np. na podstawie ratingów kredytowych niezależnych agencji (IMF, 2014: 35).

Z realizacją budżetu lokalnego, a w szczególności jego strony dochodowej, są związane ryzyko fiskalne i płynności. Niższe wpływy do budżetu będą powodowały istotne zagrożenie dla terminowej spłaty długu wraz z kosztami jego obsługi, ale również realizacji podstawowych zadań samorządu terytorialnego. Wystąpienie 
nieplanowanych wydatków lub zmaterializowanie się wcześniej wspomnianego ryzyka kredytowego zwiększy prawdopodobieństwo wystąpienia problemów płynnościowych dla lokalnych finansów. W związku z tym niezwykle ważnym zadaniem dla zarządzających finansami jest precyzyjne monitorowanie realizowanych wpływów, a w przypadku niedoboru środków finansowych dokonanie przeglądu planowanych wydatków lub ich blokowanie.

Powszechnym zjawiskiem w podsektorze samorządowym jest zaciągnięcie długu w celu spłaty zobowiązań. Dość często jest to związane z chwilową utratą płynności lub zbyt wielkimi obciążeniami JST, wynikającymi z wadliwej konstrukcji nowego wskaźnika długu i nieumiejętności zarządzania finansami. Jest to ryzyko refinansowania, powszechnie zwane też rolowaniem długu. Miara tego ryzyka jest wyrażona w latach jako wskaźnik średniej zapadalności długu. W celu ograniczenia tego ryzyka należy dążyć do wydłużenia terminu zapadalności nowo emitowanych serii obligacji (Marchewka-Bartkowiak, 2015: 209). Pomiar ryzyka refinansowania długu lokalnego zabezpiecza JST przed dokonaniem restrukturyzacji długu na niekorzystnych warunkach, a także pozwala na ograniczenie ryzyka płynności (Budzeń, 2016: 208).

Ostatnią wyszczególnioną kategorią jest ryzyko operacyjne. Może ono być w znacznej mierze kontrolowane przez zarządzających długiem. Istotne w tym obszarze są wiarygodność informacji (m.in. założenia wykorzystywane w planowaniu wieloletnim) oraz właściwa komunikacja. Odbiorcami danych są zarówno klienci wewnętrzni (poszczególne komórki organizacyjne), jak i klienci zewnętrzni (mieszkańcy, potencjalni inwestorzy). Właściwa komunikacja i przejrzyste decyzje co do zamierzonych działań składają się na proces ograniczenia tego ryzyka.

$\mathrm{W}$ grupie tej można wyróżnić m.in. ryzyko techniczne - związane z infrastrukturą teleinformatyczną. Zabezpieczenie przed awariami lub nieuprawnionym dostępem osób trzecich do różnych informacji znajduje się w gestii osób odpowiedzialnych m.in. za pion informatyczny.

W przypadku ryzyka organizacyjno-prawnego i zdarzeń losowych zarządzający długiem mają znikomą możliwość kontroli i wpływania na jego ograniczenie. Tym samym należy zwrócić uwagę, że nie należą one do istotnych zagrożeń powodujących poważne problemy finansowe, gdyż ich częstotliwość jest niewielka. Te rodzaje ryzyka są spowodowane w pierwszym przypadku zmianami regulacji prawnych dotyczącymi gospodarki finansowej JST, a w drugim przypadku - wystąpieniem klęsk żywiołowych (Poniatowicz, 2010: 120).

Kluczowe z punktu widzenia niniejszej publikacji jest ryzyko polityczne. K. Borowski (2014: 17) definiuje je jako zagrożenie dojściem do władzy ugrupowań politycznych wywołujących negatywny wpływ na funkcjonowanie i rozwój rynku finansowego. Definicja ta odnosi się jednak bardziej do rynku finansowego niż jednostek 
sektora finansów publicznych. Przejawem tego są wahania na rynku akcji w okresach wyborczych, a także bezpośrednio po wyborach. Ryzyko polityczne należy powiązać z siłą lobbingu samorządowego, a także zmianą partii rządzących na szczeblu centralnym i lokalnym, co jest efektem kadencyjności władzy publicznej (Jastrzębska, Janowicz-Lomott, Łyskawa, 2014: 40).

W kontekście jednostek sektora finansów publicznych, a w szczególności podsektora samorządowego, należy zwrócić uwagę na fakt, że ryzyko polityczne nie powinno być postrzegane wyłącznie jako zagrożenie związane ze zdobyciem władzy przez określoną grupę polityczną. Wynika ono bezpośrednio z działań ugrupowania sprawującego władzę, które w wyniku zwiększania wydatków (najczęściej inwestycyjnych) dąży do reelekcji. Przytoczone w pierwszej części teorie politycznego cyklu budżetowego potwierdzają, że zmaterializowanie tego ryzyka dotyczy w szczególności ugrupowań politycznych aktualnie sprawujących władzę.

Postrzegane w ten sposób ryzyko polityczne jest uwarunkowane wyłącznie czynnikami wewnętrznymi, co skutkuje tym, że teoretycznie stosunkowo łatwo je kontrolować. Bardzo często realizacja „wyborczych zadań publicznych”, które mają się przyczynić do reelekcji, powoduje obciążenie zobowiązaniami przyszłych pokoleń. Ponadto nieprzemyślane decyzje zarządzających długiem blokują sprawującym władzę możliwość zrównoważonego rozwoju w następnych kadencjach. Istotną rolę w ograniczaniu ryzyka politycznego powinny odgrywać wieloletnie prognozy finansowe, poprzez ich powiązanie m.in. $\mathrm{z}$ wieloletnimi planami inwestycyjnymi. Uzupełnieniem powinna być strategia zarządzania długiem, co prowadziłoby do kompleksowego zarządzania finansami lokalnymi. Należy zauważyć, że postulaty niektórych środowisk dotyczące zasady kadencyjności długu nie znajdują uzasadnienia chociażby ze względu na specyfikę systemu finansowania JST oraz charakter ich działalności. Zaciąganie długu na okres kadencji wiązałoby się z ryzykiem ograniczenia realizacji zadań publicznych, a także wzrostem obciążeń podatkowych dla społeczności lokalnej. Należy więc odrzucić możliwość odgórnego określenia limitu czasu, na który JST mogą zaciągać zobowiązania.

U. Panizza (2014: 8) zauważa, że dług publiczny może się przyczynić do marnotrawienia środków finansowych i dokonywania nieefektywnych wydatków. Wyższy poziom zadłużenia będzie skutkował jednocześnie wyższym udziałem kosztów obsługi długu w wydatkach ogółem. Mogłoby to być dobre zjawisko, gdyby zachęcało do respektowania zasady celowości wydatkowania środków publicznych. Jednak wydatki służące ponownemu wyborowi cechujące się niegospodarnością są trudne do ograniczenia właśnie ze względów politycznych. Dlatego też obsługa długu bardzo często wypiera dobre rodzaje wydatków publicznych, takie jak np. inwestycja w kapitał ludzki. 


\section{Źródła i metody badawcze}

Na potrzeby przeprowadzenia badań empirycznych, których wnioski przedstawiono w dalszej części, wykorzystano bazy danych Ministerstwa Finansów (2020) zawierające sprawozdania budżetowe JST. Okres badawczy obejmuje lata 2003-2019, co jest uzależnione od dostępności danych, jak również umożliwia identyfikację przesłanek mogących świadczyć o istnieniu ryzyka politycznego w JST w Polsce. Dla rysunków obejmujących lata 2004-2019 przyjęty okres jest determinowany potrzebą prezentacji dynamiki danego zjawiska. Dynamika została zaprezentowana w ujęciu rok do roku. Podmiotami badania są JST w Polsce z wyodrębnieniem poszczególnych typów: gmin $(\mathrm{G})$, miast na prawach powiatu (Mnpp), powiatów $(\mathrm{P})$ i województw (W). W związku z realizacją przyjętego celu badawczego wykorzystano analizę statystyczną, w tym analizę dynamiki i struktury w odniesieniu do podstawowych wielkości budżetowych: wydatków i zadłużenia.

\section{Identyfikacja ryzyka politycznego w podsektorze samorządowym w Polsce}

W tej części artykułu podjęto próbę identyfikacji możliwości wystąpienia ryzyka politycznego związanego z długiem lokalnym w Polsce. W analizowanym okresie wybory samorządowe odbyły się kolejno w latach: 2006, 2010, 2014 i 2018. Mając na uwadze cel artykułu, warto zauważyć, że istotne są kształtowanie się struktury wydatków oraz dynamika wydatków majątkowych. Jest to związane m.in. z niektórymi tezami politycznego cyklu budżetowego, zgodnie z którymi politycy dążący do uzyskania reelekcji będą oddziaływali na dokonywane wydatki budżetu poprzez zmianę ich struktury. Ponadto dla społeczeństwa bardziej widoczne są efekty w wyniku realizacji inwestycji niż w przypadku wydatkowania środków pieniężnych na zadania bieżące (np. inwestowanie w kapitał ludzki).

Rysunek 2 wskazuje na wyższy wzrost wydatków majątkowych w latach wyborczych i okresach przedwyborczych niż w pozostałych. Wysoki wzrost wydatków majątkowych powiązany $\mathrm{z}$ wyborami samorządowymi widoczny jest w przypadku wszystkich typów jednostek samorządowych. Wyjątek stanowią województwa, w których w 2010 r. zaobserwowano ujemną dynamikę wydatków majątkowych, natomiast warto zwrócić uwagę, że w 2009 r. (poprzedzającym wybory), dynamika wydatków majątkowych wyniosła 108,59\%. Tempo realizowanych inwestycji w okresach wyborczych i przedwyborczych wahało się na poziomie od $1,58 \%$ 
do 108,59\%. Pomimo że w niektórych typach JST zauważalny jest spadek inwestycji w okresach poprzedzających wybory, jednak należy poczynić zastrzeżenie, że w latach wyborczych utrzymany został wzrost poziomu wydatków majątkowych. W odniesieniu do okresów poprzedzających wybory do organów JST o jeden rok, widoczny jest minimalny spadek wydatków majątkowych w gminach i miastach na prawach powiatu w 2013 roku.

Rysunek 2. Dynamika wydatków majątkowych JST w Polsce w latach 2004-2019 (w \%)

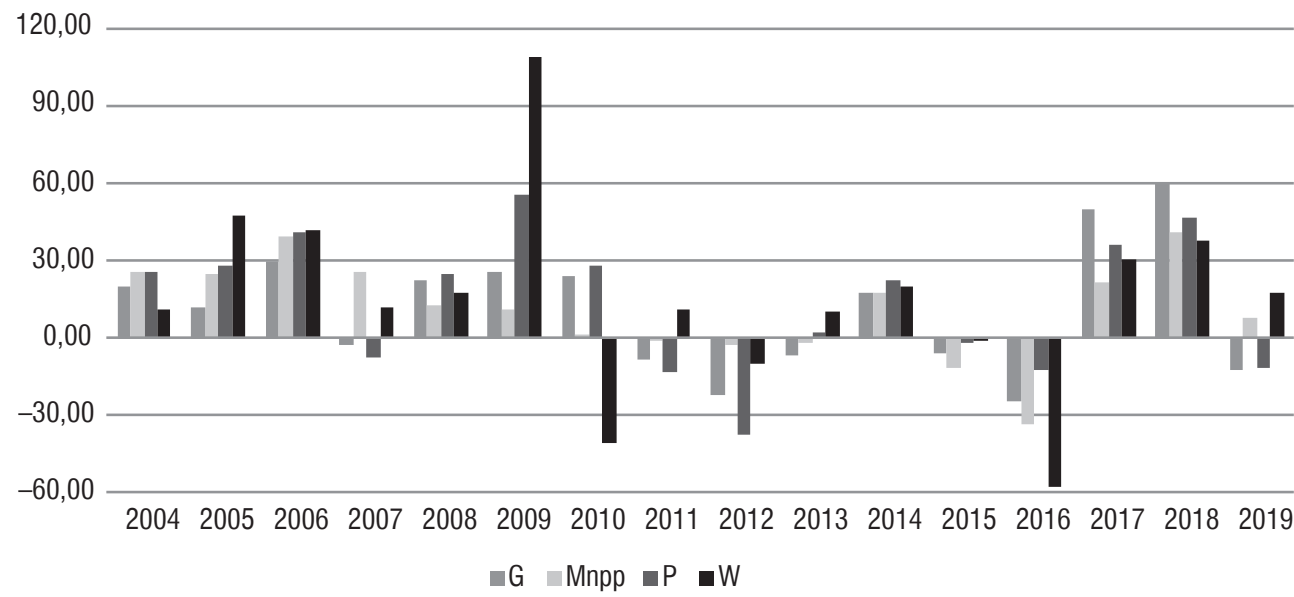

Źródło: opracowanie własne na podstawie baz danych Ministerstwa Finansów (2020).

Wyższy wzrost inwestycji w okresie wyborów samorządowych pozwala stwierdzić, że osoby sprawujące władzę zwiększały wydatki inwestycyjne w okresie wyborczym. Miało to wywrzeć wpływ na wyborców, czego skutkiem byłaby reelekcja. Takie działania można umiejscowić w nurcie zakładającym istnienie oportunistycznych partii politycznych i nieracjonalnych wyborców.

Po przeanalizowaniu kształtowania się wydatków majątkowych należy zwrócić uwagę na wynik budżetu JST. Na podstawie danych zawartych na rysunku 3 zauważalna jest prawidłowość, że w latach wyborczych i poprzedzających te okresy o rok, widoczny jest wzrost deficytu budżetu. Opisana sytuacja występuje we wszystkich latach wyborczych (2006, 2010, 2014 i 2018), co wskazuje na wykorzystywanie środków publicznych w celu uzyskania reelekcji. Sformułowaną tezę dodatkowo potwierdza fakt, że w latach wyborczych deficyt był każdorazowo wyższy niż w pozostałych latach objętych badaniem. Zatem uzasadnione jest stwierdzenie istnienia przesłanek potwierdzających występowanie zjawiska politycznego cyklu budżetowego w polskich JST. 
Rysunek 3. Wynik budżetów JST w latach 2003-2019 (w mln PLN)

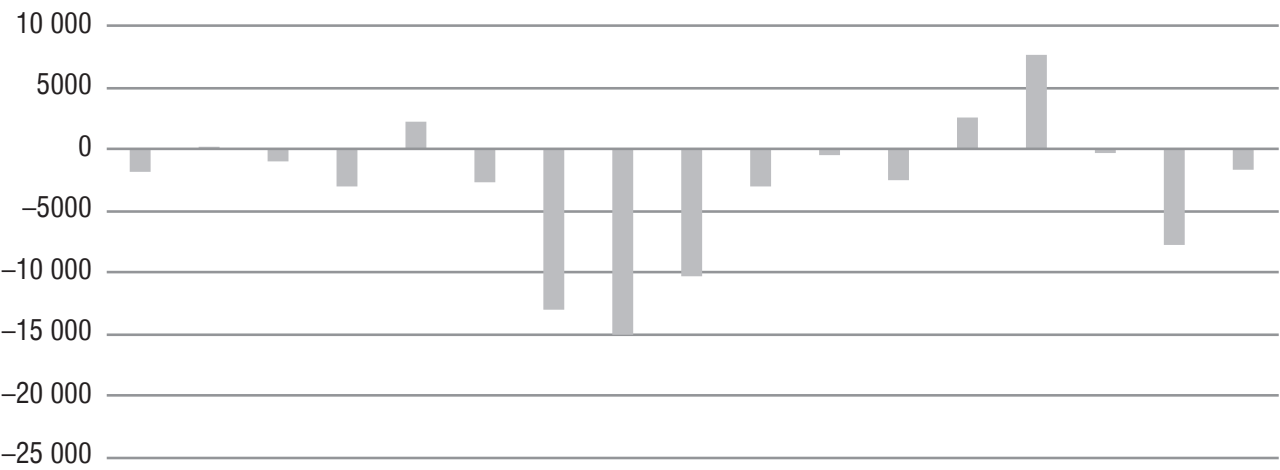

20032004200520062007200820092010201120122013201420152016201720182019

Źródło: opracowanie własne na podstawie baz danych Ministerstwa Finansów (2020).

Rysunek 4. Dynamika zadłużenia nominalnego JST w latach 2004-2019 (w \%)

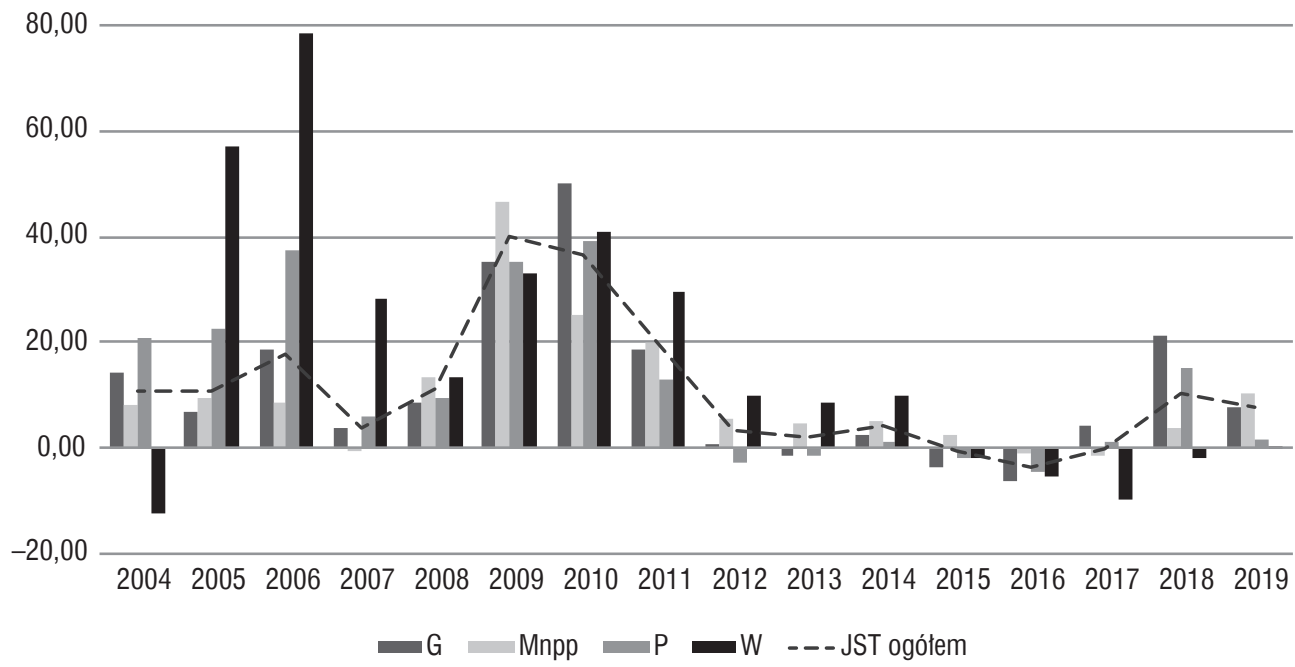

Źródło: opracowanie własne na podstawie baz danych Ministerstwa Finansów (2020).

Kolejnym krokiem w celu identyfikacji symptomów wystąpienia ryzyka politycznego w polskich samorządach jest analiza wielkości nominalnej długu lokalnego. Zostało to pokazane na rysunku 4. Widoczny jest wzrost zobowiązań w latach wyborczych i okresach przedwyborczych. Wyjątek stanowi 2017 r., w którym odnotowano ujemną dynamikę długu lokalnego. Wówczas wzrost długu nastąpił wyłącznie w przypadku gmin i powiatów. Warto zauważyć, że w 2018 r. odnotowano najwyższe tempo przyrostu zadłużenia właśnie w gminach i powiatach. W połączeniu z danymi dotyczącymi inwestycji i deficytu uzasadnione jest spostrzeżenie, że wspólnym 
mianownikiem analizowanych danych jest cykl wyborczy w samorządzie terytorialnym. Okresom wyborczym towarzyszyło wyższe tempo wzrostu zadłużenia JST. Na przyspieszenie dynamiki w zakresie wzrostu poziomu zadłużenia JST wskazują również dane dotyczące tempa tego zjawiska w odniesieniu do wszystkich typów JST. Zarówno w okresach wyborczych, jak i poprzedzających wybory do organów JST, widoczna jest wyższa dynamika wzrostu poziomu długu lokalnego. Natomiast w latach następujących bezpośrednio po wyborach samorządowych zauważalna jest tendencja spadkowa. Świadczy to o tym, że istnieją przesłanki do stwierdzenia, iż zjawisko politycznego cyklu budżetowego występuje w lokalnej polityce finansowej.

Przeprowadzona analiza potwierdza, że przyrost długu publicznego w okresach wyborczych jest efektem wzrostu inwestycji w tych latach, a te z kolei stanowią pochodną działań lokalnych polityków w celu ich reelekcji na kolejną kadencję. W tym miejscu należy poczynić zastrzeżenie, że brak jest skutecznych mechanizmów zarządzania tym ryzykiem. Obecne restrykcje prawne nie chronią dostatecznie przyszłych pokoleń przed obciążeniami związanymi ze spłatą długu zaciągniętego w celu sfinansowania deficytów budżetowych mających się przyczynić do reelekcji lokalnych polityków.

Cel artykułu, którym była próba identyfikacji przesłanek wskazujących na wystąpienie politycznego cyklu budżetowego w samorządzie lokalnym w Polsce, został osiągnięty. Na podstawie przytoczonych danych uzyskano wyniki, które o tym świadczą. Brak kompleksowego zarządzania finansami lokalnymi powoduje ryzyko marnotrawienia środków publicznych w szczególności w okresach wyborczych. Znajdują tu odzwierciedlenie przytoczone w artykule rozważania U. Panizzy, który twierdził, że wzrost długu może się przyczynić do wypierania dobrych wydatków. Może to występować przede wszystkim w okresach wyborczych.

Podsumowując należy stwierdzić, że z punktu widzenia procesów decyzyjnych w zakresie długu lokalnego niezbędne jest nie tylko wypracowanie właściwej strategii zarządzania długiem lokalnym, ale również skonstruowanie skutecznych mechanizmów ograniczających ryzyko polityczne. Zarządzanie ryzykiem powinno znaleźć odzwierciedlenie m.in. w procesie kontroli zarządczej, a dokładniej w procedurze zarządzania ryzykiem. Jednak nie wykluczy to zagrożenia związanego z cyklem wyborczym w kontekście zmiany struktury wydatków, zaciągania długu, a często także niegospodarności środkami publicznymi. Innym sposobem ograniczenia analizowanego ryzyka mogłoby być określenie w systemie prawnym maksymalnej granicy wzrostu wydatków budżetowych. Wówczas politycy nie mieliby możliwości zwiększenia wydatków budżetu np. ponad wskaźnik inflacji. Jednak należy poczynić 
zastrzeżenie, że mogłoby to powodować naruszenie samodzielności finansowej JST. W Polsce obowiązuje reguła równoważenia budżetów bieżących, którą można traktować jako narzędzie zabezpieczające przed ryzykiem. Sposób jej funkcjonowania pozwala jedynie na ograniczenie wydatków bieżących, natomiast nie dotyczy wydatków majątkowych.

Wnioski z przeprowadzonej analizy stanowią asumpt do podjęcia próby określenia wskaźnika ryzyka politycznego. W tym celu w wyniku dalszych prac pogłębione zostaną wyniki badań empirycznych. Ponadto wskazują na istnienie przesłanek wystąpienia politycznego cyklu budżetowego w podsektorze samorządowym w Polsce. Świadczy to o konieczności zwrócenia uwagi przez zarządzających długiem na szkodliwe skutki zmaterializowania się ryzyka politycznego. Materializacja ryzyka może spowodować znaczące ograniczenie możliwości absorpcyjnych środków zewnętrznych, np. w kolejnej perspektywie unijnej. Może to negatywnie wpłynąć na zdolność JST do spłaty i obsługi zadłużenia, spowodować wzrost ryzyka płynności, a w skrajnych przypadkach przyczynić się do niewypłacalności podmiotu. Zatem u władz lokalnych i osób zarządzających długiem niezbędna jest świadomość istnienia ryzyka politycznego, a także negatywnych skutków wynikających z realizacji tego ryzyka. Zarządzanie ryzykiem politycznym powinno więc być częścią odpowiedzialnie prowadzonej polityki finansowej organów JST.

\section{Bibliografia}

Alesina, A., Tabellini, G. (1990). A positive theory of fiscal deficits and government debt. The Review of Economic Studies, 57(3): 403-414. DOI: 10.2307/2298021.

Bitner, M., Cichocki, K., Sierak, J. (2013). Standardy zarzadzania dlugiem na szczeblu lokalnym i regionalnym oraz ich wptyw na finansowanie infrastruktury. Warszawa: Instytut Badań Systemowych PAN.

Borowski, K. (2014). Miary ryzyka na rynku akcji i obligacji. Warszawa: Difin.

Budzeń, D. (2016). Refinansowanie długu lokalnego w Polsce. Nowe tendencje w zarządzaniu finansami publicznymi. Studia BAS, 3(47): 195-217.

Cichocki, K. (2013). Zarzadzanie finansami i dlugiem samorządu terytorialnego w perspektywie wieloletniej. Warszawa: Instytut Badań Systemowych PAN.

Denek, E., Dylewski M. (2013). Szacowanie poziomu zadłużenia jednostek samorzadu terytorialnego $w$ warunkach zwiększonego ryzyka utraty plynności finansowej. Warszawa: Difin.

Działo, J. (2007). Wpływ czynników politycznych na instrumenty i efekty polityki gospodarczej. Gospodarka Narodowa, 5-6: 25-44.

Hibbs, D. (1977). Political Parties and Macroeconomic Policy. The American Political Science Review, 71(4): 1467-1487. DOI: 10.2307/1961490. 
IMF (International Monetary Fund) (2014). Revised Guidelines for Public Debt Management. Washington: IMF. https://www.imf.org/external/np/pp/eng/2014/040114.pdf (dostęp: 1.08.2020).

Jastrzębska, M., Janowicz-Lomott M., Łyskawa K. (2014). Zarządzanie ryzykiem w działalności jednostek samorządu terytorialnego ze szczególnym uwzględnieniem ryzyka katastroficznego. Warszawa: Wolters Kluwer.

Kalecki, M. (1943). Political Aspects of Full Employment. The Political Quarterly, 14: 1-9. DOI: 10.1111/j.1467-923X.1943.tb01016.x.

Kamiński, A. (2012). Finansowanie dłużne w jednostkach samorządu terytorialnego. Warszawa: Wolters Kluwer.

Marchewka-Bartkowiak, K. (2008). Zarzadzanie długiem publicznym. Teoria i praktyka państw Unii Europejskiej. Warszawa: WN PWN.

Marchewka-Bartkowiak, K. (2015). Ryzyko refinansowania długu. W: Leksykon budżetowy: 209. G. Gołębiowski, K. Marchewka-Bartkowiak (red.). Warszawa: Wyd. Sejmowe.

Ministerstwo Finansów (2019). Strategia zarządzania długiem sektora finansów publicznych w latach 2020-2023. Warszawa: Ministerstwo Finansów. https://www.gov.pl/web/finanse/ strategie-zarzadzania-dlugiem (dostęp: 20.07.2020).

Ministerstwo Finansów (2020). Bazy danych sprawozdań budżetowych. https://www.gov.pl/ web/finanse/sprawozdania-budzetowe (dostęp: 19.08.2020)

Pacześ, P. (2011). Doświadczenia Polski w świetle teorii politycznego cyklu koniunkturalnego. Polityka gospodarcza w świetle kryzysowych doświadczeń - Prace i Materiały Instytutu Rozwoju Gospodarczego SGH, 85: 215-239.

Panizza, U. (2014). Public Debt Risks in Italy. Myths, Facts, and Policies. Graduate Institute of International and Development Studies Working Paper, 13: 1-13.

Poniatowicz, M., Salachna, J., Perło, D. (2010). Efektywne zarządzanie długiem w jednostce samorządu terytorialnego. Warszawa: Wolters Kluwer.

Próchnicki, L. (2012). Rola deficytu budżetowego w gospodarce - ewolucja teorii. Studia i prace Wydziału Nauk Ekonomicznych i Zarzadzania, 27: 163-186.

Rogoff, K., Sibert, A. (1988). Elections and Macroeconomic Policy Cycles. Review of Economic Studies, 55(1): 1-16.

Samuelson, P., Nordhaus, W. (2000). Ekonomia 1. Warszawa: WN PWN.

Stankiewicz, W. (2007). Historia myśli ekonomicznej. Warszawa: PTE.

Persson, T., Tabellini, G. (2003). Do Electoral Cycles Differ Across Political Systems? (March 2003). IGIER Working Paper, 232. DOI: 10.2139/ssrn.392643.

Ustawa z dnia 27 sierpnia 2009 roku o finansach publicznych, Dz. U. 2021, poz. 305.

Veiga L.G., Veiga F.J. (2004). Political Business Cycles at the Municipal Level. NIPE Working Papers, 4: 1-26. DOI: 10.2139/ssrn.533682.

Unless stated otherwise, all the materials are available under 